\title{
Pillars and Elements to Develop an Open Business Model for Innovation Networks
}

\author{
Evelyn Rojas ${ }^{1}$ and Américo Azevedo ${ }^{2,3}$ \\ ${ }^{1}$ Faculdade de Engenharia Mecânica-UNICAMP, Rua Mendeleyev, 200-CEP 13083-860, \\ Cidade Universitária "Zeferino Vaz" Barão Geraldo, Campinas, São Paulo, Brasil \\ ${ }^{2}$ INESC TEC, Campus da FEUP, Rua Dr. Roberto Frias, 4200-465, Porto, Portugal \\ ${ }^{3}$ FEUP - Faculty of Engineering, University of Porto, Rua Dr. Roberto Frias, \\ 4200-465 Porto, Portugal \\ paolasoto@fem.unicamp.br, ala@fe.up.pt
}

\begin{abstract}
Innovation networks are seen as an important opportunity for organizational performance by facilitating the creation of new knowledge, not just transferring existing knowledge. Collaboration in innovation between manufacturing companies and research centers is a trend that continues to grow in importance linked to business success. Embedded in the literature on business models in the context of networks organizations, this paper propose key pillars and elements required in order to support the establishing of open business model for innovation networks. Subsequently the use of these elements in practice was verified through empirical research evidence in a case study.
\end{abstract}

Keywords: Open innovation, Innovative Networks, Open Business Model, Value Creation, Value Capture.

\section{Introduction}

The success of many companies can be attributed to the way they have innovated in their businesses; challenging established organizations and changing the rules of competition [1]. Currently, although the advantages and benefits of the paradigm of networks are well known, the research focused on developing a business model for organizations in networks is still at a nascent stage and represents a gap in research. An organization's business model is its driver for success, because it operationalizes the entrepreneurial opportunity that creates competitive advantages for the organization in its market [2], [3]. In this paper we take a business model as the logical representation of a firm's choices to create; delivery and capture value [4].

In the context of networked organizations, one of the main challenges to ensure their survival in the market is the ability create a business models that allows operating the opportunity of entrepreneurship identified in the market and generate revenues under changing environmental [5]. Therefore, the intended study in this paper aims to answer the need for empirically based research that contributes to the management of networks organizations, specifically of innovation networks by identifying a pillars and set of elements that enable them to establish an open business 
model. With this, we intend to highlight that there are key components that define an open business model differentiating them from closed and static models.

This paper is organized as follows. Section 2 reviews the literature about Innovation Networks (IN) and open business model definitions in order to build a theoretical background that supports the identified business model elements for IN. Section 3 presents the research methodology and section 4 the paper's theoretical contribution by describing the six main pillars and the fourteen elements of an open business model for IN. Evidence from a pilot case study is presented and discussed in Section 5. Finally, section 6 concludes the paper.

\section{$2 \quad$ Literature Review}

\subsection{Innovation Networks}

Innovation has become widely recognized as the cornerstone that makes businesses successful [6]. But, studies also highlight the importance of networks for innovation success [7]. This premise is also supported by the open innovation literature that stands the importance of external agents in fostering innovation [8]. Through Open Innovation, organizations can access to novel technology, product, or new markets that extend beyond of their actual core businesses and that would be difficult to discover in individual form [9]. Open innovation is defined as a distributed innovation process based on knowledge flows managed across organizational boundaries, using pecuniary and non-pecuniary mechanisms in line with the organization's business model [10]. Hence, components like networks of innovators and knowledge transference between firms and research institutions have become significant contexts for innovation. Although there are a wide variety of research works focused on the emerging area of collaborative business networks, there are few contributions on the management processes in the context of innovation networks [11]. In this sense, further research is needed in this area that is growing in importance and becoming relevant for managers, due to the impact in the fields of science and technology, also the variety of actors involved [12].

In general, innovation networks approach reflects the vision of the conjunction between innovation, technological opportunities and user necessities. According to Landsperger [13], innovation networks are an organizational solution that enables companies to deliver complex products or innovative services, through the integration of different organizational skills. Product innovation results from the assembly of dispersed resources, knowledge and capabilities embedded in a range of firms. Incentives for participating in networks are sharing risk, granting access to complementary assets, generate economies of scale, shared knowledge and facilitating collective learning. In order to develop the business model for innovation networks important aspects must be considered: the value captured in a network of innovation depends on the volume of knowledge exchange, the alignment of the objectives of the network and how the resources of the participants are combined and managed within the network. 


\subsection{Open Business Model}

Business model has been the subject of a growing number of studies. However, researchers and practitioners have not developed yet a common and widely accepted language on the topic. Actually, looking into the literature, we find several different constructs of the concept. Various definitions of business models are presented in Table 1.

Table 1. Definitions of business model in literature

\begin{tabular}{lc}
\hline \multicolumn{1}{c}{ Definition } & Source \\
\hline "A business model is a concise representation of how an interrelated set of & {$[14]$} \\
decision variables in the areas of venture strategy, architecture, and economics are & \\
addressed to create sustainable competitive advantage in defined markets". & \\
"A business model elucidates how an organization is linked to external & {$[15]$} \\
stakeholders, and how it engages in economic exchanges with then to create value & \\
for all exchange partners". & \\
"A business model is the heuristic logic that connects technical potential with the & {$[16]$} \\
realization of economic value". & \\
"A business model is a set of choices and the set of consequences arising from & {$[17]$} \\
those choices". These set of choices are developed by an organization to achieve & \\
profit. & \\
"A business model describes the rationale of how an organization creates, delivers & [18] \\
and captures value. & \\
\hline
\end{tabular}

It is noteworthy that the basic function of business model is to describe the design of the value creation and capture mechanisms needed to achieve profit by combining the firm's internal and external factors [15], [19]. In the literature, it was observed that most of the works on the business models are explored from a traditional perspective, i.e., the designs focus on a single company [18], [20], [21], that has a linear value chain and develops within a stable and predictable competitive landscape; this scenario represents a static concept of business models. Traditional approaches of business models face difficulties to cover the wide scope required for organizations structured in flexible and dynamic networks, because the result might not be efficient [22]. Innovation networks are developed in a context of open innovation, which involves capture to phenomena such as the commercialization of intellectual property, integration of server and client, collaborative processes of R\&D [23]. In this sense, the construction of their business model cannot be seen from a perspective of a single firm, nor can be considered static; being necessary use a new approach that considers an open business model focused on external resources as key contributors to a firm's value creation process where the value for the customer is co-created between actors in a network [24].

Thus, developing an open business model for innovative networks would imply that each member of the network open its business model, by actively researching and the exploiting of external and internal ideas, allowing their unused internal technologies to flow to the outside [16]. This context provides new sense to develop a business model where traditional business models components have to be coupled with the development of relational capabilities and the capacity to manage networks of actors. 
There are still few contributions on the development of business models from the perspective of network organization [22], [25], [26]. Among existing previous works can be indicated the proposal by Palo and Tähtinen [26] who developed an empirically grounded conceptualization of a networked business model. The authors identified the generic elements of a business model in the field of technology-based services and propose to use these elements to build a networked business model. On the other hand, Helander and Rissanen [27] developed a theoretical study in which they highlighted that in a network context the business model of a company must be linked to the business model of the other companies involved in the partnership. In addition, Komulainen et al. [28] identified three core elements for a network business model: product/service, business actors and their roles, and value-creating exchanges among the actors. Other important contribution in business model for collaborative networks is the work of Loss \& Crave [22] who explores the concept of Agile Business Models that enable a fast reaction and better adaptation of collaborative networks into dynamic markets, this research work also includes the identification of innovation levers and barriers when designing business models for collaborative networks. Also, we highlight Romero's contribution that provides the guidelines to define a VBE business model considering a multi-value system characterization and a multi-stakeholder perspective, proposing at the same time the main elements to be concerned in approaching a VBE governance model [29].

In an attempt to address the phenomenon of open business models, the challenge in this paper focused on the issue of identified key pillars and elements to setting up an open business model that allows the co-creation of value between the various actors in the network, considering its possible heterogeneity.

\section{$3 \quad$ Research Methodology}

This research aims to analyse which are the relevant pillars and elements for setting up an open business model of an innovation network? To answer this, we utilize an exploratory methodology, which was conducted in two phases. First, we used the literature search method to integrate multiple bodies of literature on areas of open innovation, networked organizations, innovation networks and business model development; in order to identify and select the key pillars and set of elements suitable to develop an open business model according to the innovation networks perspective. Second, based in a case study approach, we carried out a pilot study to verify if the pillars and set of business model elements proposed are considered in practice.

The unit of analysis is an innovation network and the data collection method used was two semi-structured interviews, one with the IN coordinator and the other with IN members. Interviewer bias was countered with the use of an interview guide, the presence of two interviewers and tape recording of the interviews. For data analysis it was performed content analysis in order to facilitate the perception of the business model elements present in the network under study. The data of the interviews was combined and structured and inductively coded into six main pillars and fourteen elements. In the next sections we introduce the pillars and the set of business model elements proposed and present the pilot case study. 


\section{$4 \quad$ Pillars and Elements to Develop an Open Business Model for Innovation Networks}

Through a qualitative analysis of the proposals of 57 authors who contributed from different perspectives, either through definitions of business model, either by identifying specific components for a business model, or propose taxonomies, tools, or others; were identified six main pillars of a business model: Customer, Network Value Creation, Network Actors, Network Value Exchange, Network Value Capture and Network Governance; and fourteen elements to represent an open business model for IN, based on qualitative analyses of existent approaches of different authors in literature about business models and open innovation, networked organizations and innovation network's approach. In Table 2 are defined each business model element.

Table 2. Definitions of the business model elements

\begin{tabular}{|c|c|}
\hline Element & Definition \\
\hline \multicolumn{2}{|l|}{ Customers } \\
\hline Customer needs & $\begin{array}{l}\text { Problem that a customer intends to solve with the purchase of a good, } \\
\text { service or product-service systems. }\end{array}$ \\
\hline \multicolumn{2}{|c|}{ Network Value Creation } \\
\hline $\begin{array}{l}\text { Value proposal } \\
\text { offered }\end{array}$ & $\begin{array}{l}\text { Promise of a collection of goods, services and product-service systems. } \\
\text { to be delivered by the IN to the customer in order to solve his/her } \\
\text { problem. }\end{array}$ \\
\hline Core competencies & Specific skills and technologies of each member. \\
\hline $\begin{array}{l}\text { Network Key } \\
\text { Activities }\end{array}$ & $\begin{array}{l}\text { The most important activities carried out by the IN members in order to } \\
\text { execute the value proposition. }\end{array}$ \\
\hline \multicolumn{2}{|l|}{ Network Actors } \\
\hline Actors and roles & $\begin{array}{l}\text { Members of the IN, and role each partner plays within the IN. Describes } \\
\text { each actor positioning and the value it creates in the IN. }\end{array}$ \\
\hline $\begin{array}{l}\text { Partners Evaluation } \\
\text { Criteria Definition }\end{array}$ & Criteria used to accept or exclude a member in the IN. \\
\hline \multicolumn{2}{|c|}{ Network Value Exchange } \\
\hline Shared Resources & $\begin{array}{l}\text { List of resources and activities that are shared among IN partners in } \\
\text { order to create competitive advantages. }\end{array}$ \\
\hline Shared Information & $\begin{array}{l}\text { Type of information to be exchanged among partners for efficient } \\
\text { management of the IN. }\end{array}$ \\
\hline Technology Support & $\begin{array}{l}\text { Information and communication software supporting the functioning } \\
\text { and management of the IN. }\end{array}$ \\
\hline \multicolumn{2}{|c|}{ Network Value Capture } \\
\hline Cost & $\begin{array}{l}\text { Expenditures that the IN members have in creating (providing a good or } \\
\text { service and coordinating with the other partners) and distributing the } \\
\text { offered value. }\end{array}$ \\
\hline Revenues & The way a IN generates its income. \\
\hline
\end{tabular}

Our proposal considers structural and behavioral aspects to facilitate a better understanding of an open business model. Pillars such as Customers, Network Value Creation, Network Actors and Network Value Capture have a structural nature, which 
defines the relevant elements and their relationships. The behavioral aspect defines how these elements interact. The Network Value Exchange and Network Governance pillars belong to this group. These components bring dynamism to the business model. Where firms interact with one another, weaving an ever-changing network of interactions into which they can embed themselves or getting out in any time. A representation of pillars and set of elements and their linkages that form the basis for open business model is showed in Figure 1.

An essential element is the identification of the customer's needs of the network, in order to define the value offered to a customer through an innovative solution. The definition of the Value proposal offered is a key element of the Networked Value Creation pillar. This element is the basis to define the Network key activities and the core competences required for development the product offered by the network. Actors and roles as Partners Evaluation Criteria Definition are the elements of the pillar Networked Actors. Based in the matching of requirements and competences, actors with complementary skills are selected in order to reach a maximum of synergy between the different processes and transfer knowledge.

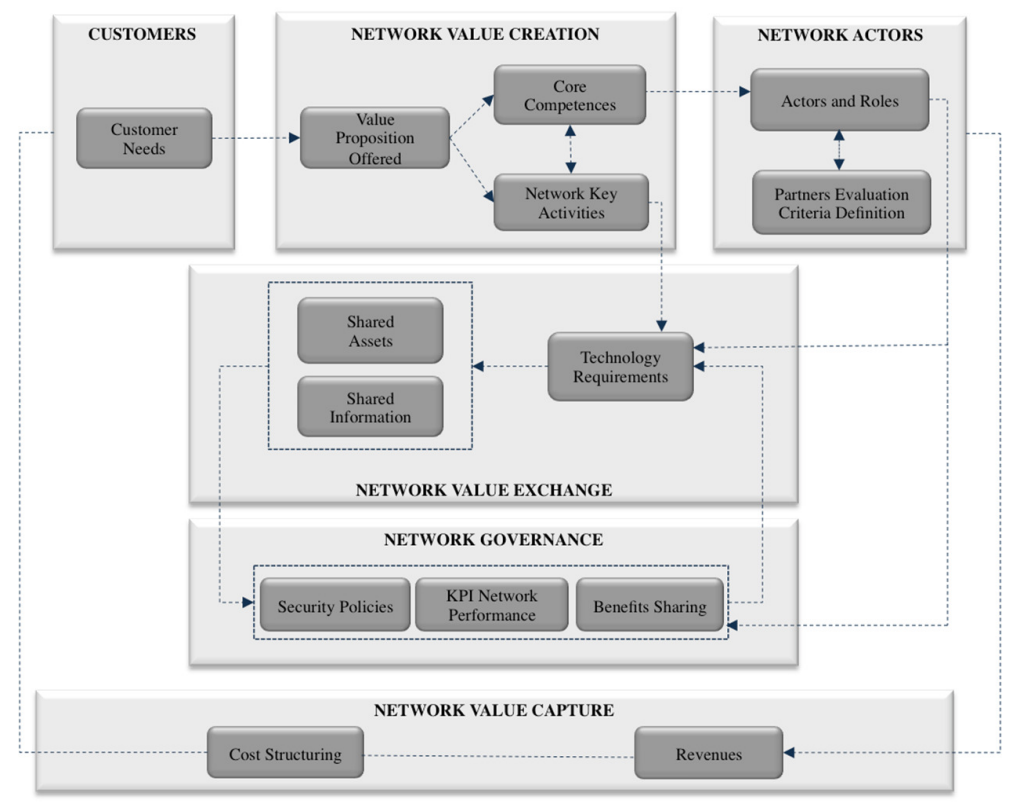

Fig. 1. Representation of pillars and set of elements and their linkages

Network Value Exchange depicts the transactions (transfer and transformation) and the effective combination of the different information and assets (resources, capabilities, know-how, goods/ services) between all the actors, showing how they create value, not only for the network's end customer but also for the network's partners [29]. The important elements to be considered are: shared assets, shared information and technology requirements. Network Value Capture or value appropriation, according to 
West [30], explains how the value creation is captured in order to sustain the business activity. The Network value capture elements identified were: Cost structure that considers all expenditures involving with creating, offering, and distributing goods and services; and Revenues source generated [26].

Network Governance refers to the different instruments that assess the performance level of the network, maintain a strict control of information, resources and capabilities of all actors in the network. The Network Governance elements identified were: security policies, KPI network performance and benefits sharing.

\section{Case Study}

The goal of the following case study is to understand and validate the applicability of the envisioned business model elements. Our study concentrates on an Innovation Network created in the Northern region of Portugal in order to develop new products derived from cork material, and maintain its successful performance in the international market. The network offered products with applications in different areas such as footwear and accessories, home and office design and transportation industry. Currently the network has some products in development phase and others in production phase. We choose to study the partnership established to develop a new material to be applied in footwear industry. The network value proposition is to offer an innovative cork fabric that intends to be positioned among animal hides and synthetic fabrics. This fabric can be used in an infinite number of forms, shapes and purposes, especially in products where the cork application is a totally new concept. Actors, roles and task descriptions are clear in the network. Organization consists of (a) Company " $\mathrm{A}$ " who is a responsible for providing rolls and cork panels to form cork blades with increased strength and flexibility. This company had the initiative to form the network and plays the network manager role and is responsible for selecting the best-suited partners to develop this new material. (b) Company " $\mathrm{B}$ " is a graphic industry who defines the type of inks that can be used on new cork material (c) Technological research center, which is responsible for technological testes in order to ensure that the new material is suited to applications for which it was developed and reaches ISO levels. (d) Company "C", footwear industry, is the one that coordinates the network and verifies the compliance with the specifications and requirements of the developed material.

The criterion for the choice of network members is the credibility demonstrated by results and information obtained from previous projects. The network manager emphasized that the selection of partners through personal networks facilitates trust between network members, moreover to surpass obstacles as time and bureaucracy. Sharing the know-how and interdisciplinary actions of partners contribute favorably to the development of new technologies, industrial processes and capabilities of employees. This enables the creation of a new cork based product (vegetable leather) for use in specific applications in footwear industry. Due to a lack of standards for this innovative process, the network performance evaluation has been done in a very informal way. Aiming to ensure the governance of the network, the network's coordinator signs specific agreements for each company member, and monitors the 
flow of information between participants. Cost structure involved internal and external activities; services and human resources cost and uncertainty cost of the external activities related to the value-added process. These costs are allocated in the planning phase for each member. The allocation of revenues is based on the participation level during the value-creation process. Among the expected benefits, the network partners believe that working in collaboration in the form of the socalled innovation network is essential to create credibility in the market. Without collaboration, this cork product would be released to the market without a substantial and solid base of knowledge and would not be accepted by the target markets.

Evidence from the case study shows, that the defined business model elements are present in this case. However, further research is needed to validate these elements in more complexes networks.

\section{Conclusions}

New organizational structures based on networks and collaboration led to adopt new perspectives to build business models, which are based on openness. The understanding of these open business models in the literature is still quite low and dispersed.

While most previous studies have focused on traditional business models (static based on an individual company), our study aimed to identify key pillars and elements to setting up an open business model that allows the co-creation of value between the various actors in the network considering its heterogeneity. In this way our research, considering the existing literature and the empirical study, allowed us to identify fourteen elements classified in six main pillars: Pillar: Customer (Element: Customer Needs); Pillar: Network Value Creation (Elements: Value proposal offered by network; Core Competences; Network Key Activities); Pillar: Network Actors (Elements: Actors and Roles; Partners Evaluation Criteria Definition); Pillar: Network Value Exchange (Elements: Shared Assets; Shared Information and Technology Requirements); Pillar: Network Value Capture (Elements: Cost Structuring and Revenues); Pillar: Network Governance (Elements: Security Policies, KPI Network Performance and Benefits Sharing).

Through the development of the pilot case study we were able to collect evidence, which suggests that the defined business model elements are present in innovation networks. However, we invite future research to further explore this young field of open business model, because more research is needed for building dynamic architectures that support network organizations.

Acknowledgments. The research leading to these results has received funding from the European Union Seventh Framework Programme (FP7/2007-2013) under grant agreement $n^{\circ}$ FoF-ICT-2011.7.3 - 285220 (Adventure Project - ADaptive Virtual ENterprise ManufacTURing Environment). INESC TEC team research was also supported by the Project "NORTE-07-0124-FEDER-000057", financed by the North Portugal Regional Operational Programme (ON.2 - O Novo Norte), under the National Strategic Reference Framework (NSRF), through the European Regional 
Development Fund (ERDF), and by national funds, through the Portuguese funding agency, Fundação para a Ciência e a Tecnologia (FCT).

\section{References}

1. Swan J. and Scarborough, H. The politics of networked innovation, Human Relations, Vol.58, No.7, pp.913-943, (2005)

2. Klang D., Wallnöfer M., Hacklin F. The anatomy of the business model: a syntactical review and research agenda. DRUID Summer Conference 2010" Opening Up Innovation: Strategy, Organization and Technology, (2010).

3. Baden-Fuller C. and Morgan M. S., Business models as models. Long Range Planning Vol.43. No.2, pp. 156-171, (2010)

4. Rojas, E. P. S., Barros, A. C., de Azevedo, A. L., \& Batocchio, A. Business model development for virtual enterprises. In Collaborative Networks in the Internet of Services (pp. 624-634). Springer Berlin Heidelberg, (2012)

5. Alt, R. \& Zimmermann, H. Preface: introduction to special section-business models. Electronic Markets. 11.1: 3-9, (2001)

6. Tidd, J., Bessant J. Managing Innovation. Chichester: John Wiley and Sons, 4th edition, (2009)

7. Wuyts, S., Dutta, S., Stremersch, S. Portfolios of interfirm agreements in technologyintensive markets: Consequences for innovation and profitability. Journal of Marketing, 68(2), 88-100, (2004)

8. Laursen, K.,Salter, A. Open for innovation: The role of openness in explaining innovation performance among UK manufacturing firms. Strategic Management Journal, 27(2), 131-150, (2006)

9. Almirall, E., Casadesus-Masanell, R. Open versus closed innovation: a model of discovery and divergence. Academy of Management Review, 35(1), 27-47, (2010)

10. Chesbrough, H., Bogers, M. Explicating open innovation: clarifying an emerging paradigm for understanding innovation. In: Chesbrough, H., Vanhaverbeke, W., West, J. (Eds.), New Frontiers in Open Innovation. Oxford University Press, Oxford (2014)

11. Moller, K. K., Svahn, S. How to influence the birth of new business fields. Industrial Marketing Management, 38, 450-458, (2009)

12. Geels, F. W. Technological transitions as evolutionary reconfiguration processes: a multilevel perspective and a case-study. Research Policy, 31(8-9), 1257-1274, (2002)

13. Landsperger J.,Spieth P. Managing innovation networks in the industrial goods sector. International Journal of Innovation Management Vol.15 No.6, pp. 1209-1241, (2011)

14. Morris, M.; Schindehutte, M. and Allen, J. The entrepreneur's business model: toward a unified perspective. Journal of Business Research, 58, pp.726-735, (2005)

15. Zott,C; Amit R..and Massa,L.The business model: Theoretical roots, recent developments and future research. IESE Business School-University of Navarra, pp.1- 43, (2010)

16. Chesbrough, H. Why companies should have open business models. MIT Sloan Management Review, 48(2), 22-28, (2007)

17. Casadesus-Masanell, R; Ricart J. From Strategy to Business Models and onto Tactics. Long Range Planning, Elsevier Ltd. Vol. 43, N. 2-3, pp. 195-215, (2010) 
18. Osterwalder A., Pigneur, Y. Business model generation-a handbook for visionaries, game changers, and challengers, (2010)

19. Teece, DJ. Business model, business strategy and innovation. Long Range Planning, 43, 172-194, (2010)

20. Amit, R., Zott, C. Value creation in E-business. Strategic Management Journal, v. 22, n. 67, p. 493-520, jun. (2001)

21. Hedman, J., Kalling, T. The business model concept: theoretical underpinnings and empirical illustrations. European Journal of Information Systems, 12.1: 49-59, (2003)

22. Loss L., Crave S.Agile Business Models: an approach to support collaborative networks, Production Planning \& Control: The Management of Operations, 22:5-6, 571-580, (2011)

23. Gassmann, O., Enkel, E., Chesbrough, H.W. The future of open innovation. R\&D Management 40 (3), 213-221, (2010)

24. Storbacka, K. A solution business model: Capabilities and management practices for integrated solutions. Industrial Marketing Management, 40(5), 699-711, (2011)

25. Moller, K., Rajala, A. "Rise of strategic nets - New modes of value creation", Industrial Marketing Management, Vol 36, pp. 895-908, (2007)

26. Palo,T., Thtinen, J. A network perspective on business models for emerging technologybased services, Journal of Business \& Industrial Marketing,Vol.26 Iss:5, pp.377-388, (2011)

27. Helander, N. and Rissanen, T. "Value-creating networks approach to open source software business models", Frontiers of E-Business Research, pp. 840-54, (2005)

28. Komulainen, H.; Mainela, T.; Sinisalo, J.; .Tahtinen J. and Ulkuniemi, P. Business model scenarios in mobile advertising, International Journal of Internet Marketing and Advertising, Vol. 3 No. 3, pp. 254-70, (2006)

29. Romero, D., et al..Towards the definition of business models and governance rules for virtual breeding environments. In: L.M. Camarinha-Matos, H. Afsarmanesh and M. Ollus, eds. Network-centric collaboration and supporting frameworks. New York: Springer Publisher, 103-110, (2006)

30. West, J. Value Capture and Value Networks in Open Source Vendor Strategies, in Proceedings of the 40th Annua Hawaii International Conference on System Sciences (HICSS'07), Hawai, pp. 176-186, (2007) 